\title{
Reconstruction of the Inheritance Rights of Illegitimate Children in Indonesia Based on the Values of Justice
}

\author{
Gunarto $^{1 *}$, Syarief Husien ${ }^{2}$, Akhmad Khisni ${ }^{3}$ \\ ${ }^{1}$ Faculty of Law Sultan Agung Islamic University Semarang, Indonesia \\ ${ }^{2}$ Doctorate Student of Faculty of Law Sultan Agung Islamic University Semarang, Indonesia \\ ${ }^{3}$ Faculty of Law Sultan Agung Islamic University Semarang, Indonesia
}

DOI: $10.36348 /$ sijlcj.2021.v04i04.006

| Received: 13.03.2021 | Accepted: 19.04.2021 | Published: 22.04.2021

*Corresponding author: Gunarto

\section{Abstract}

The research of this article is motivated by the formulation in the Marriage Law No. 1 of 1974 where there are several articles that regulate the inheritance rights of illegitimate child, namely article 42 and article 43 that are not just as there is no attainment of justice in the inheritance rights of illegitimate child so that the child has not received welfare in his life therefore it need to be reconstructed to achieve justice. This research is a non doctrinal/ socio legal research which is descriptive analysis. With the constructivism paradigm. This research approach method is empirical, supported with normative and comparative approach. Primary data sources are interviews, observations, while secondary data sources are primary, secondary and tertiary legal materials which are then collected and analyzed using data triangulation. The result shows that the inheritance rights of illegitimate child is not yet fair because there is no attainment of justice in the inheritance rights of illegitimate child so that the child has not received welfare in his life, therefore, a reconstruction Inheritance rights of children outside of marriage based on the value of justice is needed by adding another paragraph in Article 43, that states that the civil position in the law gave no distinction between children outside of marriage and within marriage or gave one side a prioritize over other.

Keywords: Reconstruction, Inheritance Rights, Illegitimate Children, Justice Value.

Copyright () 2021 The Author(s): This is an open-access article distributed under the terms of the Creative Commons Attribution 4.0 International License (CC BY-NC 4.0) which permits unrestricted use, distribution, and reproduction in any medium for non-commercial use provided the original author and source are credited.

\section{INTRODUCTION}

Illegitimate children are children born by a woman, who is outside of the marriage bond with the man who performs intercourse with her. Meanwhile, the definition of outside marriage is the relationship between a man and a woman who can give birth to offspring, while their relationship is not in a legal marriage bond according to positive law and the religion he adheres to [1].

This problem is closely tied to The law of inheritance as it is related to the scope of human life, because every human being will eventually experience legal events. Children born out of wedlock get the nickname in society as illegitimate children, this causes psychological problems for the child, although legally the child does not have legal consequences due to the actions of their parents, there are many problems that arise as a result of the extramarital pregnancy, such as the Nasab (parental relationship) between children and their biological father from legal perspectives, and so on [2].

In the Islamic Law Compilation (KHI), although the provisions of each heir have been determined based on the provisions in the Qur'an, it does not rule out the distribution according to the agreement of the heirs after realizing their respective parts. This is in accordance with Article 183 which stipulates that the heirs can agree to make peace in the distribution of inheritance after each realizes their share.

Then, according to the Civil Code, the definition of illegitimate children is divided into two types, namely as In a broad sense, an outside child is married because of adultery and incest. Adultery is a child born from an extramarital relationship between a man and a woman where one or both of them are married to another person. Meanwhile, a donated child is a child born from a relationship between a man and a woman, where between the two, based on the 
Gunarto et al., Sch Int J Law Crime Justice, Apr, 2021; 4(4): 227-232

provisions of the law, there is a prohibition against marrying each other such as that both of them are brother and sister. And then, there are out-of-wedlock children or illegitimate children, where, in the narrow sense is a child born outside of a legal marriage. The status of children born outside of a legal marriage is a problem for these out-of-wedlock children because they cannot get their rights and position as children in general like legitimate children because legally, they only have a civil relationship with their mother and their mother's family only.

Furthermore, Children, according to Indonesian law, are classified into 2 (two) categories, namely legitimate children and illegitimate children. Article 42 of the Marriage Law No. 1 of 1974 states that legitimate children are children born in or as a result of a legal marriage and Article 43 paragraph (1) of the Marriage Law No. 1 of 1974 explains that children who were born outside of marriage only have a civil relationship with their mother and their mother's family only. Children born in or as a result of a legal marriage and the result of a legal husband and wife conception outside the womb by medical means and born by the wife are legal children according to Article 99 of the Islamic Law Compilation.

In the Compilation of Islamic Law, legal children are contained in Article 99a which states that "a legitimate child is a child born in or as a result of a legal marriage". So it can be concluded from the article according to the Compilation of Islamic Law that if there is a child born outside of a legal marriage, it can be stated that the child is an illegitimate child or an adulterous child. Meanwhile, the position of children according to Islamic law as stated in the Islamic Law Compilation in principle, is the same as the Civil Marriage Law because Article 100 of the Islamic Law Compilation states that "Children born outside of marriage only have a Nasab relationship with their mother and their mother's family". And Article 43 paragraph (1) of the Marriage Law states that "Children born outside of marriage only have a civil relationship with their mother and their mother's family only".

The status of the inheritance rights of children out of wedlock according to Islamic law only has an inheritance relationship with the mother and the mother's family, however, there is a need for a legal breakthrough in this regard, namely in the Islamic inheritance system, as there is a grant institutuion system where the children can be given the right by the means of giving biological father's day and it can also be in the form of Mandatory Testament from his biological father [3].

In relation to the inheritance of the illegitimate children, it can be seen that from the position of the child out of wedlock itself, wherein society, there is a rule that to be able to continue the offspring, people must first marry. The birth of offspring outside of a legal marriage is unacceptable, and the child is not recognized as the legal child of the person who birthed it. He cannot obtain the rights he could receive if he is a legitimate child such as inheritance rights, the right to use a family name, granting marriage permits, and parental powers.

The Constitutional Court Decision No.46 / PUU-VIII / 2010 only explains that children outside of marriage also have a civil relationship with the father, if it can be proven by science and technology. The Constitutional Court Decision No.46 / PUU-VIII / 2010 does not explain the parts or regulations regarding the distribution of inheritance between unmarried children and their biological father. Islamic law also does not regulate and explain the distribution of inheritance between the father's heir and the heirs from outside of wedlock. That is why there is confusion that arises when there are cases of dispute regarding the inheritance of children outside of marriage with their biological father. Even though adultery children from outside marriage are different, the diversity of positions and statuses of out-of-wedlock children is what determines whether an out-of-wedlock child can ask for and receive their rights from their biological father.

This problem are what urges the author to study it in a research as an effort to build a better law wherein this study is concentrated on 2 main problems as follows:

1. What Are The Weaknesses Of The Inheritance Rights Of An Illegitimate Child In Indonesia Currently?

2. How Is The Reconstruction Of The Inheritance Rights Of An Illegitimate Child In Indonesia Based On The Values Of Justice?

\section{METHOD OF RESEARCH}

This study uses a constructivist legal research paradigm approach. The constructivism paradigm in social science is a critique of the positivist paradigm. According to the constructivism paradigm of social reality that is observed by a person cannot be generalized to everyone, as positivists usually do.

This research uses descriptive-analytical research. Analytical descriptive research is a type of a non-doctrinal research that seeks to describe and seek answers fundamentally about cause and effect by analyzing the factors that cause the occurrence and appearance of a particular phenomenon or event.

The method of approach in research using the method (Socio-Legal Approach). The sociological juridical approach (Socio-Legal Approach) is intended to study and examine the reciprocal relationship that is associated in real terms with other social variables [4].

Sources of data used include primary data and secondary data. Primary data is data obtained from field 
Gunarto et al., Sch Int J Law Crime Justice, Apr, 2021; 4(4): 227-232

observations and interviews with sources, While Secondary Data is data consisting of:

1. Primary legal materials, namely binding legal materials in the form of prevailing laws and regulations and have something to do with the issues discussed [5].

2. Secondary legal material, namely legal material whose nature provides an explanation of the primary legal material.

3. Tertiary legal materials are legal materials that provide further information on primary and secondary legal materials.

Research that is associated with the socio-legal approach is research that analyzes problems that are carried out by combining legal materials (which are secondary data) with primary data obtained in the field, supported by prior to secondary legal materials, in the form of writings of experts and existing legal policies [6].

\section{RESEARCH RESULT AND DISCUSSION Weaknesses of the Inheritance Rights of an Illegitimate Child in Indonesia Currently}

One of the problems of inheritance law that exists in Indonesia is regarding children outside of marriage (Illegitimate Children) where there are fundamental differences between their rights and children that are born in a lawful marriage as stated in both the compilation of Islamic law, for those who adheres to the Islamic law, and the Indonesian Civil Code, for those who isn't. This encourages legislators, especially the Civil Code, to create a child recognition institution, namely against illegitimate children that are born due to adultery or by donation.

In the explanation of Article 49 of Law Number 3 of 2006 concerning Religious Courts (Law No.3 of 2006) in particular letter a, it is stated that marriage is matters that are regulated in or based on the applicable law concerning marriage which is carried out according to sharia: item 22 is the determination of the origin of a child and the determination of adoption based on Islamic law. In this case, it relates to child legalization (Istilhaq). Meanwhile, adoption is included in the meaning of adoption (Tabany). For a child who has been approved, a clear legal relationship can rose between him and his parents, as well as the inheritance rights included therein. However, the problem actually arises if the father is not willing to acknowledge or legalize his child, this raises the question of how is the legal protection for the child.

In Islamic law, a person can be said to be a child out of wedlock or an illegitimate child if the process that causes the child to exist is from an act of adultery which is prohibited by Islamic law, whether this act can be proven or not. If this action can be proven, then the provisions of Islamic law stipulate that the child does not have a family relationship with his father. Then, if the act cannot be proven, but the act of adultery really does exist, then the child will get the inheritance right from the father right from their birth.

Regarding the definition of a child out of wedlock or illegitimate children, according to Amir Syarifuddin [7], he termed it an adultery child. According to him, a child for adultery is a child born from an act of adultery, namely a sexual relationship between a man and a woman who is not bound by a legal marriage even though he was born in a legal marriage with a man who committed adultery or with another man. Meanwhile, according to Shaykh Kamil Muhammad Uwaidah [8], a child for adultery is a child born to his mother from the result of intercourse outside of marriage which is legal according to Islam. When viewed from the statutory regulations, there is no explicit mention of: the meaning of illegitimate children or illegitimate children explicitly, but this definition can be understood from several articles, including in Article 99 of the Islamic Law Compilation, it is stated that "a legitimate child is a child who born in or as a result of a legal marriage, The result of the act of a husband and wife outside the womb by medical means to then born by that wife. "Then in Article 100 Compilation of Islamic Law which states that "children born outside of marriage only have a family relationship with their mother and their mother's family".

From the statement of several articles above, it can be understood that a child can be said to be legal if his birth is included as a result of a legal marriage, on the other hand, an out-of-wedlock child or an illegitimate child is a child born outside of marriage and the consequences of an illegal relationship.

This definition can also be understood from the sound of Article 42 of Law Number 1 of 1974 concerning Marriage, which states that "a legal child is a child born in or as a result of a legal marriage". Then in Article 43 paragraph 1, which states that "children born out of wedlock only have a civil relationship with their mother and their mother's family".

Definition of illegitimate children in the Civil Code are children that are born out of wedlock according to terms used or known in civil law called natuur lijk kind. The law requires and demands that birth is not a result of sexual relations between a woman and a woman who is not bound by a bond known as the institution of marriage. However, the reality in society shows that sometimes the demands of decency and law are not fulfilled by some members of the community. Seedling and childbirth can only be justified by chastity, if they take place by means of a holy path. Thus it is stated above that a legal child is a child born in a legal marriage. So a child who is born or is seeded outside of marriage is an illegitimate child or a child that are born outside of marriage. 
Gunarto et al., Sch Int J Law Crime Justice, Apr, 2021; 4(4): 227-232

From the explanation above it can be seen that The law itself does not clearly state who can be said to be an out-of-wedlock child, but from Article $272 \mathrm{BW}$ it can be concluded that an illegitimate child who can be recognized is a child born to a mother, but who is not seeded by a man who is in a marriage bond. legal rights with the mother of the child, and is not included in the group of children who are born from adultery and children who are donated.

So from this, it can be concluded that the child outside of marriage (in a broad sense) actually includes:

a. Adultery child is a child born from a relationship between two people, a man and a woman who is not husband and wife, where one or both of them are bound by a marriage with another person. What needs to be remembered is that one or both of the parents who made the relationship and produced the child is in or still exists in the marriage bond with another person.

b. Donated children are children born from a relationship between two people who are closely related so that between them is prohibited by law from marrying.

c. Illegitimate Children. That is a child born or hatched outside of marriage.

However, with regard to children born after their father's death or divorce, so after the marriage has broken up or outside the marriage of their parents, it is not necessarily an illegitimate child because when the baby is seeded, the mother is in a legal marriage and born within 300 days after the marriage is broken, then the baby can be included as a legitimate child. So what is meant by children outside of marriage is children outside of marriage in the narrow sense.

According to the system adopted in The Indonesian Civil Code (BW), even with the existence of offspring outside of marriage, there has not been a family relationship between the child and the parents who birthed it. Only after the recognition (Erkenning) was issued a kinship with all its consequences, especially the right to inherit the meaning of the child and the parents who recognized it. However, a familial relationship between the child and the family of the father or mother who acknowledges it does not yet exist. That relationship can only be established with child validation (Weltiging), which is a step further than acknowledgment. It should be noted that the law does not allow the admission of adulterous and donated children.

So, in terms of extramarital confession it is categorized into two parts, namely:

a. It should not be admitted, that is, children born from adultery relations are called adultery children, and irregular relationships are called donated children. b. Admittedly, namely natural children who are legally recognized (Erkend Kinderen). These recognized children may also be legalized (Gevettig) and natural children who are not recognized as legal (Notuurlik Niet Erke D Kinderen).

Based on that it can be admittedly said that there are levels of legal status for out-of-wedlock children and that is:

a. Children outside of marriage, this child has not been recognized by the mother and father.

b. Children outside of marriage that has been recognized by one or both parents

c. The child outside the marriage becomes a legal child as a result of his parents entering into a legal marriage.

\section{Reconstruction of the Inheritance Rights of an Illegitimate Child in Indonesia Based On the Values of Justice}

Legally speaking, the relationship between the child and the man who raises him and his family in the field of family law is considered non-existent, so in this case, there is no inheritance law between the two, this is embraced in both the Islamic Law Compilation and the Civil Code. This has prompted legislators, especially the Civil Code, to create a recognition institution, which has legal consequences for the child, including in this case, the recognized inheritance rights of the illegitimate child. However, the problem actually arises if the father is not willing to acknowledge his child, how is the legal protection for the child?

In the Islamic Law Compilation, it is stated that children born outside of legal marriages only have a lineage with the mother and their mother's family only (Article $100 \mathrm{KHI}$ ), so that the out-of-wedlock child only inherits from the mother and the mother's family (Article $186 \mathrm{KHI}$ ). This also applies to sirri marriages, marriages that are only done according to the Islamic tradition and not registering the marriage through a nationally-approved procedure because in principle every marriage must be registered (Article 5 paragraph $1 \mathrm{KHI})$.

There are differences and similarities regarding the status of the inheritance rights of out-of-wedlock children. Both the Compilation of Islamic Law and Civil Law each have their own advantages and disadvantages in regulating children outside of marriage. However, the Compilation of Islamic Laws still provides more legal protection to the child. Regulators and law enforcers, both in the Compilation of Islamic Law and Civil Law, should re-update the regulations in order to produce stricter provisions regarding the recognition of children outside of marriage which also have an impact on legal certainty regarding the share of their inheritance. 
Gunarto et al., Sch Int J Law Crime Justice, Apr, 2021; 4(4): 227-232

Prior to the Constitutional Court decision No. 46 / PUU-VIII / 2010, children born from unmarried marriage have the same legal status as out-of-wedlock children, that is, they only have a legal relationship with their mother (see Article 43 paragraph (1) of Law No. 1 of 1974 on Marriage).

This has a consequence, children born from unmarried marriage, by law, the state does not have a legal relationship with their father. This can be seen, among other things, from the child's birth certificate. In the birth certificate of a child born from a siri marriage, it is stated that a child has been born whose name is, the day and date of birth, the order of birth, the mother's name and the date of the mother's birth (mentioning the mother's name only, does not mention the name of the child's father). This is regulated in Article 55 paragraph (2) letter (a) of PP No. 37 of 2007 concerning the Implementation of Law no. 23 of 2006 concerning Population Administration.

In addition, the consequence of the absence of a relationship between father and child legally also results in illegitimate children not inheriting from their biological father. However, the Constitutional Court (MK) through the Constitutional Court decision No. 46 / PUU-VIII / 2010 concerning the examination of article 43 paragraph (1) of the Marriage Law states that children born outside of wedlock have a legal relationship with the biological father, not only to the mother and the mother's family.

As the explanation of the statement above, when the position of the child here is clear, as stated in the Civil Code and Law No.1 of 1974 concerning Marriage, the next thing that needs to be examined is the right of the child outside of marriage to inherit from his father, which currently, the part of the inheritance of children outside of marriage according to the Civil Code is as follows:

a. Illegitimate children get one third of the share if the deceased leaves a legal offspring according to the law or the husband or wife's agreement. (Article 863)

b. Illegitimate children get half of the share if the deceased does not leave their offspring, husband or wife, but leaves a blood family in the line of descent and above, or brothers and sisters. (Article 863)

c. Illegitimate children get three-quarters if those who die only leave their blood relatives to a further degree. (Article 863)

d. The share of the Illegitimate child who has been recognized must be given first, then the remainder is distributed to the legal heirs. (Article 864)

e. Illegitimate children inherit all the assets of the heir if the heir does not leave a legal heir according to the law. (Article 865)

The inheritance rights of Illegitimate children in Islamic law according to the Qur'an and the Hadiths continue to ordain children outside of marriage to their mothers and relatives [9].

Seeing the difference between Islamic inheritance rights and in the Civil Code in settling the legal rights of children outside marriage, it is necessary to reconstruct the regulations in this study, the researcher wants to add a theoretical renewal, namely the theory of Siyasah Syar'iyyah (Legal Breakthrough) [10] where The Inheritance Rights of Children Outside Marriage are included in a new article which is expected to obtain justice in getting the right it deserves, considering that there is no wrongdoing by the birth of a child because a child is basically a gift from God, which means that they deserve prosperity in their life, and for the distribution must also see how much devotion to his parents, for example, because of a woman get fewer rights even though during the life of the parents the daughter was always there under any circumstances. Likewise, for the rights of children outside of marriage that are not recognized in the inheritance rights of children outside marriage, it is necessary to have certainty in the law that is expected to get justice and gain welfare.

Based on the foregoing, the Reconstruction of Inheritance Rights of Children Outside Marriage Based on the Value of Justice, namely in Article 43 paragraph (1) of Law no. 1 of 1974 which was originally: "(1) Children born out of wedlock only have a civil relationship with their mother and their mother's family and with men as their father which can be proven based on science or technology and/ or other evidence according to law. has a blood relationship, including a civil relationship with his father's family". After the reconstruction of Article 43 paragraph (1) of Law no. 1 of 1974 needs to be changed to: "(1) Children born out of wedlock only have a civil relationship with their mother and their mother's family and with men as their father which can be proven based on science or technology and / or other evidence according to the law. blood relations, including civil relations with his father's family".

\section{CONCLUSION}

1. The weakness of the regulation of inheritance rights for children outside of marriage in Indonesia currently is their position is below the child that is born in marriage as stated in Article 43 paragraph (1) of Law no. 1 of 1974 where if the illegitimate child dies first, then they can be replaced by the legitimate children so that the inheritance only applies to the out-of-wedlock child who is recognized by the father and/ or mother, which means without acknowledgment from the father and/ or mother, the child that is born outside marriage does not have the right to inherit. The same thing can be seen in the Islamic inheritance law that applies in Indonesia, where children 
outside of marriage only have a civil relationship with their mother and their mother's family only.

2. In order for the existence of children outside of marriage in terms of the right to inherit is in accordance to the value of justice, Article 43 paragraph (1) of Law no. 1 of 1974 needs to be reconstructed to: "(1) Children born out of wedlock only have a civil relationship with their mother and their mother's family and with men as their father which can be proven based on science or technology and/ or other evidence according to the law that could prove blood relations, including civil relations with his father's family". With this reconstruction, the inheritance position is assured to be able to provide justice as the law will give no distinction between children outside of marriage and within marriage or gave one side a priority over other.

\section{REFERENCES}

1. Yunanto. (2017). Recognition Of Illegitimate Children In Various Laws In Indonesia, Diponegoro Law Review, April 2017, Volume 02, Number 01

2. Pusvita, Sari. (2018). Keperdataan Anak diluar Nikah dalam Putusan Mahkamah Konstitusi dan Implikasinya terhadap Harta Warisan. Ulul Albab:
Jurnal Studi dan Penelitian Hukum Islam. 1. 31. 10.30659/jua.v1i2.2338.

3. Surini Ahlan Sjarif. (2005). Masalah Perkawinan Dan Waris, Ghalia, Indonesia, p.10.

4. Faisal. (2010). Menerobos Positivisme Hukum. Rangkang Education, Yogyakarta.

5. Johnny Ibrahim. (2005). Teori dan Metodologi Penelitian Hukum Normatif, Bayumedia, Surabaya.

6. L. Moleong. (2002). Metode Penelitian Kualitatif. PT Remaja Rosdakarya, Bandung

7. Amir, in Subekti. (1989). Kaitan Undang-undang Perkawinan dengan Penyusunan Hukum waris, Jakarta, p.5.

8. Shaykh, in Idris Ramulyo. (2000). Perbandingan Pelaksanaan Hukum Kewarisan Islam dengan Kewarisan Menurut Kitab Undang-undang Hukum Perdata (BW). Second Edition, Jakarta, Sinar Grafika, p.20.

9. Asman, Asman. (2020). Hamil Diluar Nikah Dan Status Nasab Anak (Studi Analisis Perspektif Imam Syafi'i Dan Imam Ahmad Bin Hambal). Shar-E: Jurnal Kajian Ekonomi Hukum Syariah. 6 10.37567/shar-e.v6i1.83.

10. Jamil, Abdul. (2008). Cara Berhukum yang Benar Bagi Profesional Hukum (Ijtihad Sebagai Terobosan Hukum Progresif). Jurnal Hukum Ius Quia Iustum. 15. 10.20885/iustum.vol15.iss1.art1. 